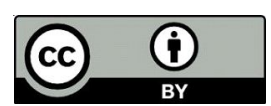

UDC 347.918 .2

LBC 67.410
Submitted: 06.07.2021

Accepted: 01.09.2021

\title{
THE COMPARATIVE LAW RESEARCH OF REMISSION IN ARBITRATION ${ }^{1}$
}

\author{
Ekaterina P. Rusakova \\ Peoples' Friendship University of Russia, Moscow, Russian Federation \\ Viktor V. Zaitsev \\ Peoples' Friendship University of Russia, Moscow, Russian Federation
}

Introduction: the institute of remission has only received significant development since 2016 with the adoption of the arbitration reform and the introduction of appropriate changes concerning remission. To date, the legal framework for the procedure for the return of the state court in case of finding serious shortcomings of the arbitration decision has not been fully formed. The purpose of the study: to analyze the remission in the arbitration court after the state court has returned the arbitration decision to correct significant shortcomings. Relevance: the importance and relevance of the work are since the regulations of Russian arbitration institutions do not have provisions on remission. The regulations of foreign arbitration institutions only contain a reference to remission, but do not disclose in detail the conduct of this procedure. At the same time, the institute of remission plays a significant role in arbitration proceedings. The number of applications to this procedure in foreign countries, as well as the beginning of its development in Russia, emphasizes the need and relevance of the study. Methods: in the paper, the research methodology includes the general scientific methods of cognition, specific scientific methods, and special legal methods, the comparative method of analyzing the rules of arbitration institutions is used, and the systematic method is used to determine the formation of the former composition of the arbitration or the new one. Results: the rules of the relevant arbitration institution should be considered as the applicable rules for remission. As a general rule, remitted issues are considered by the same panel of arbitrators that previously made the relevant award. The validity of the arbitrators' mandate depends on the relationship between the remitted issues and the arbitration decision. The arbitration refusal of remission must be justified. Based on the results of remission, a new decision or an additional one may be made. Conclusions: the institution of remission is important, as it allows you to effectively and quickly correct significant shortcomings while avoiding the cancellation of the arbitration decision, and preserve the partnership of the parties. Based on the analysis and the conclusions drawn, the authors' own rules are formulated, which can be included in the rules of arbitration institutions.

Key words: remission, return of the arbitral award to the arbitral tribunal, arbitration panel, essential deficiencies, the mandate of the arbitrator.

Citation. Rusakova E.P., Zaitsev V.V. The Comparative Law Research of Remission in Arbitration. Legal Concept $=$ Pravovaya paradigma, 2021, vol. 20, no. 4, pp. 47-57. (in Russian). DOI: https://doi.org/10.15688/lc.jvolsu.2021.4.6

УДК 347.918 .2

Дата поступления статьи: 06.07.2021

ББК 67.410

Дата принятия статьи: 01.09.2021

\section{СРАВНИТЕЛЬНО-ПРАВОВОЕ ИССЛЕДОВАНИЕ РЕМИССИИ В АРБИТРАЖЕ ${ }^{1}$}

\section{Екатерина Петровна Русакова}

Российский университет дружбы народов, г. Москва, Российская Федерация

Виктор Васильевич Зайцев

Российский университет дружбы народов, г. Москва, Российская Федерация

Введение: существенное развитие институт ремиссии получил только в 2016 г. после принятия третейской реформы и внесения соответствующих изменений в отношении ремиссии. На сегодняшний день не до 
конца сформирована правовая база процедуры возвращения решения арбитража государственным судом в случае обнаружения серьезных недостатков. Цель исследования: анализ проведения ремиссии в третейском суде после того, как государственный суд вернул решение арбитража для исправления существенных недостатков. Актуальность: важность и актуальность данной работы вызвана тем, что регламенты российских арбитражных учреждений не имеют положений о ремиссии. Регламенты иностранных арбитражных учреждений содержат лишь упоминание о ремиссии, но не раскрывают подробно проведение данной процедуры. При этом институт ремиссии играет существенную роль в третейском разбирательстве. Количество обращений к данной процедуре в зарубежных странах, а также начало ее развития в России подчеркивает необходимость и актуальность исследования. Методология: в настоящей статье методология исследования включает в себя обще- и частнонаучные, а также специально-юридические методы, применяется сравнительный метод анализа регламентов арбитражных учреждений, системный метод используется при определении вопроса формировании прежнего состава арбитража или нового. Результаты: в качестве применимых правил к ремиссии следует рассматривать правила соответствующего арбитражного учреждения. По общему правилу ремитированные вопросы рассматривает тот же состав арбитров, который ранее вынес соответствующее арбитражное решение. Действие мандата арбитров зависит от взаимосвязи ремитированных вопросов и решения арбитража. Отказ арбитража от ремиссии должен быть обоснован. По результатам ремиссии может быть принято новое или дополнительное решение. Выводы: институт ремиссии представляет важное значение, так как позволяет эффективно и быстро исправить существенные недостатки, избежав при этом отмену решения арбитража, и сохранить партнерство сторон. На основе анализа и сделанных выводов сформулированы собственные правила, которые могут быть включены в регламенты арбитражных учреждений.

Ключевые слова: ремиссия, возвращение решения арбитража третейскому суду, состав арбитража, существенные недостатки, мандат арбитров.

Цитирование. Русакова Е. П., Зайцев В. В. Сравнительно-правовое исследование ремиссии в арбитраже // Legal Concept= Правовая парадигма. - 2021. - T. 20, №4. - C.47-57. -DOI: https://doi.org/10.15688/lc.jvolsu.2021.4.6

\section{Введение}

В России институт ремиссии появился в 1993 г. после принятия Закона о МКА [4]. Положение, регламентирующее процедуру ремиссии, было закреплено в п. 4 ст. 34 Закона о МКА. Наиболее известен данный институт в англо-американской системе права. В ст. 8 Закона о судопроизводстве в судах общего права Англии 1854 г. впервые появилось положение о ремиссии [20]. Позже ремиссия получила свое развитие и в континентальной системе права.

Ремиссия (от лат. Remissio - «обратная отправка») представляет собой особую процедуру, в которой осуществляется взаимодействие государственного и третейского суда. Процедура заключается в обнаружении государственным судом существенных недостатков арбитражного решения и возможности возвратить / ремитировать (от лат. Remittere) решение третейскому суду. В свою очередь третейский суд возобновляет арбитраж и исправляет ошибки [1]. Использование такой терминологии позволяет точно определить данное явление, именно данный термин сле- дует применять как общепринятый. При этом следует отметить, что в российской судебной практике он практически не встречается, чаще употребляется формулировка «возобновление третейским судом разбирательства».

В России ремиссия не получила эффективного применения на практике и существенного теоретического развития. До 2016 г. стороны третейского суда и государственные суды редко прибегали к процедуре ремиссии. Ситуация изменилась после вступления в силу положений о ремиссии 1 сентября 2016 года. Были закреплены положения, регламентирующие процедуру ремиссии, а именно ч. 5 ст. 420 , ч. 8 ст. 425 ГПК РФ; ч. 5 ст. 232 и ч. 8 ст. 238 АПК РФ; ч. 6 ст. 37 ФЗ № 382 [10].

В качестве научных работ можно отметить работы С.А. Курочкина, в которых некоторые разделы затрагивают институт ремиссии [5] и научную статью Д.А. Андреева, в которой кратко, но очень точно, освящены все имеющиеся проблемы института ремиссии в арбитраже. Д.А. Андреев приводит статистические данные, согласно которым с момента проведения реформы в 2016 г. как минимум 10 дел суды общей юрисдикции и арбитраж- 
ные суды согласились ремитировать. В пяти делах были исправлены дефекты, обозначенные государственном судом, а главное удалось избежать отмены арбитражного решения (среди таких дел: Постановление Арбитражного суда Уральского округа от 20.02.2018 N Ф09-652/18 по делу N А07-1154/2017; Постановление Арбитражного суда Уральского округа от 26.04.2018 N Ф09-1508/18 по делу N A71-22793/2017; Постановление Арбитражного суда Московского округа от 12.03.2019 N Ф05-1689/2019 по делу N А40-203696/18).

Теоретической и методологической основой исследования послужило законодательство Российской Федерации, арбитражные регламенты арбитражных учреждений, труды отечественных и иностранных ученых, материалы научных конференций. Методология исследования включает в себя общенаучные методы познания (диалектический, формальнологический), частнонаучные методы (исторический, этнографический, антропосоциологический, статистический) и специально-юридические методы (юридико-догматический и сравнительно-правовой). Теоретико-методологическая составляющая исследования представлена трудами отечественных и иностранных авторов - С.А. Курочкин [5], Д.А. Андреев, Г.В. Севастьянов, И.В. Решетников [7], Beata Gessel-Kalinowska vel Kalisz [15].

Из общенаучных методов следует выделить наиболее важные, а именно, диалектический и логический.

Использование первого из них вызвано характером объекта и предмета исследования, который требует изучения проблематики исследования как реально существующих, в их постоянном развитии и взаимосвязи с другими явлениями, процессами, закономерностями и т. д., такими как взаимодействие государственного суда и арбитража, влияние ремиссии на отмену решений арбитража.

Логический метод обеспечит обоснованность, достоверность и непротиворечивость выводов, сформулированных в результате исследования.

Использование частнонаучных методов:

1. Системный метод (предполагающий акцент на взаимодействии явлений, их единстве и взаимосвязях, и целостности) - будет использован, например, при определении вопроса фор- мировании прежнего состава арбитража или нового. Системные аспекты были сформулированы на основе трудов Beata Gessel-Kalinowska vel Kalisz [15], В.В. Хвалей [11].

2. Структурно-функциональный метод (предполагающий определение места, роли и функций каждого элемента изучаемой системы) - важен при определении роли ремиссии. Также при анализе процедуры проведения ремиссии. Структурно-функциональную основу исследования составили работы авторов - С.А. Курочкина, С.А. Абесадзе [6] и Д.А. Андреева.

3. Социологический метод (предполагающий установление связей государства и права с иными социальными явлениями) - будет использован при объяснении того, почему важен институт ремиссии для сторон спора. При анализе социологических аспектов основу исследования составили работы авторов - Н.А. Чудиновская, О.Ю. Скворцов [6].

Институт ремиссии соответствует духу третейского разбирательства, выступает инструментом эффективного исполнения решения арбитража. Благодаря ремиссии у сторон есть возможность сэкономить время и собственные расходы. Одним из важных значений является избежание отмены решения арбитража. В случае отмены решения арбитража сторонам придется заново пройти все стадии разбирательства, что несомненно скажется на экономической составляющей контрагентов. Исходя из этого, ремиссия должна получить широкомасштабное применение в третейском разбирательстве.

Ремиссию можно рассматривать в двух основных аспектах: процедура ремиссии в государственном суде и ремиссия в арбитраже. В данной работе предлагается уделить внимание второму блоку - проведение процедуры ремиссии в арбитраже. Актуальность данного исследования вызвана тем, что ни российское законодательство, ни регламенты третейских судов не содержат положений о том, каким образом арбитраж может рассматривать ремитированные вопросы, исправлять дефекты арбитражного решения. Главное значение института ремиссии заключается в возможности избежать отмены арбитражного решения. Вышеназванные причины, а также практическое отсутствие нормативной базы 
о том, как арбитраж должен или может рассматривать ремитированные вопросы и исправлять ошибки решения, создает необходимость написания данной работы.

\section{Исследование}

\section{1. Правила применения процедуры ре- миссии}

Российские постоянные арбитражные учреждения не имеют положений, регламентирующих, каким образом арбитраж должен рассматривать ремитированные вопросы и исправлять ошибки. В связи с этим необходимо обратиться к опыту иностранных арбитражей. Для начала следует рассмотреть правила Международной торговой палаты, где впервые в 2012 г. были приняты специальные правила о ремиссии. Согласно п. 1 ст. 36 Арбитражного регламента Международной торговой палаты [3] состав третейского суда вправе по своей инициативе исправить допущенные в арбитражном решении описки, ошибки в подсчетах или опечатки либо иные ошибки аналогичного характера (далее по тексту предлагается использовать обобщающее название «дефекты» как серьезные недостатки, позволяющие государственному суду вернуть решения арбитража третейскому суду), с условием, что такие исправления будут направлены суду для их одобрения в течение 30 дней с даты вынесения решения арбитража.

Что касается сторон, то в соответствии с п. 2 этой же статьи стороны вправе обратиться с ходатайством в Секретариат об исправлении дефектов, которые были упомянуты в п. 1, в течение 30 дней с даты получения решения арбитража в количестве экземпляров, которые указаны в п. 1 ст. 3 Арбитражного регламента Международной торговой палаты. Секретариат передает ходатайства составу арбитража, которые предоставляются стороной в срок 30 дней для дачи комментариев. Составом арбитража может быть установлен иной срок. После истечения срока предоставления комментариев арбитраж должен направить проект своего решения по ходатайству в суд. Аналогичная процедура применяется, если сторона обратилась с ходатайством о толковании решения арбитра- жа. Решение об исправлении или толковании арбитражного решения оформляется как дополнение и является частью арбитражного решения.

При этом важно отметить, что данные положения регулируют только процедуру исправления дефектов и толкование решения арбитража. Институт ремиссии урегулирован в п. 4 ст. 36 Арбитражного регламента МТП. Важно также обратить внимание на названии самой статьи, в которой перечислено две процедуры, то есть пп. 1-3 ст. 36 Арбитражного регламента МТП регулируют процедуру исправления дефектов и толкование решения арбитража, а п. 4 ст. 36 этого же документа регламентирует процедуру ремиссии. В таком случае содержится лишь упоминание о процедуре ремиссии без подробной регламентации о том, как состав арбитража должен рассматривать ремитированные вопросы.

Арбитражный регламент Бельгийского центра арбитража и посредничества (далее CEPANI) [12] содержит такую же структуру статьи, то есть вначале содержатся положения об исправлении дефектов и толковании решения арбитража, а затем процедура ремиссии. Арбитражный регламент CEPANI не отличается от Арбитражного регламента МТП, в п. 8 ст. 36 Арбитражного регламента CEPANI все также содержится лишь упоминание о ремиссии без подробного разъяснения о том, как должны быть рассмотрены арбитрами ремитированные вопросы. Данное положение о ремиссии появилось в 2013 г. (п. 6 ст. 33 CEPANIArbitrationRules (2013). Арбитражный регламент CEPANI от 2020 г. был дополнен п. 10 ст. 36, согласно которому, если не представляется возможным восстановить прежний состав арбитров, он будет восстановлен в соответствии со ст. 17 Арбитражного регламента CEPANI. Из данного пункта можно сделать вывод о том, что ремитированные вопросы должен рассматривать тот же состав арбитража, который первоначально рассматривал спор, однако об этом позже. В результате Арбитражный регламент CEPANI также содержит лишь упоминание о ремиссии.

В Арбитражном регламенте Венского международного арбитражного центра (далее - VIAC) [2] встречается немного другая 
конструкция, которая отличается тем, что рассматриваемые нами выше процедуры, а именно исправление дефектов, толкование и ремиссия содержатся в разных статья. Вопросы исправления регламентированы ст. 39 Арбитражного регламента VIAC, а вопросы ремиссии - ст. 40 Арбитражного регламента VIAC. Последняя ничем не отличается от рассмотренных выше положений двух разных арбитражных учреждений, здесь все также содержится лишь упоминание о ремиссии.

Арбитражные регламенты / правила других иностранных постоянных арбитражных учреждений не имеют положений о проведении процедуры ремиссии. Регламенты российских постоянных арбитражных учреждений также не имеют регламентации процедуры ремиссии. При этом в Регламенте Арбитражного центра при РСПП [8] содержится ст. 60 Возобновление полномочий арбитров, которую можно принять за ремиссию, однако это не так. В данном случае словосочетание «возобновление полномочий арбитров» употребляется как обобщающее название процедуры исправления дефектов (ст. 61 Регламента), принятия дополнительного решения (ст. 62 Регламента), разъяснения решения (ст. 63 Регламента). В связи с этим в Регламенте Арбитражного центра при РСПП также не содержится положений о ремиссии.

Несмотря на то, что в регламентах иностранных арбитражных учреждений содержится лишь упоминание о ремиссии и отсутствует процедура рассмотрения ремитированных вопросов арбитрами, представляется возможным вывести общие правила для ремиссии, а именно:

- суд оказывает содействие в соблюдении условий, которые могут быть определены сторонами, возвращения составу арбитража ремитированных вопросов;

- Секретариат постоянно действующего арбитражного учреждения оказывает содействие составу арбитража исполнить все требования решения суда;

- суд может установить аванс на покрытие любых дополнительных расходов и гонораров состава арбитража, а также дополнительных административных расходов третейского суда;

- при возобновлении арбитражного разбирательства применяются те же самые пра- вила того же самого регламента, насколько это возможно для ремитированных вопросов;

- ремитированные вопросы должен рассматривать тот состав арбитров, который ранее разрешал данный спор и выносил по нему решение;

- арбитраж по результатам ремиссии может вынести либо новое арбитражное решение, либо дополнение к предыдущему решению.

Таким образом, в настоящее время в мировой практике имеется лишь упоминание о процедуре ремиссии в арбитражных регламентах [9]. В российских регламентах третейских судов не содержится каких-либо положений о ремиссии. При этом можно говорить о сформировавшихся общих правилах, которые могут стать отправной точкой для дальнейшего развития института ремиссии и формирование этих общих правил как принципов ремиссии. В качестве применимых к ремиссии правил следует рассматривать правила соответствующего арбитражного учреждения. Если арбитражный регламент не содержит положений о ремиссии, следует рекомендовать сторонам использовать положения о ремиссии других арбитражей как наилучшую практику.

\section{2. Возвращение решения арбитража:} состав арбитража, мандат арбитров, отказ от ремиссии

При возвращении решения арбитража государственным судом третейскому суду немаловажным вопросом является состав арбитража, который должен будет рассмотреть ремитированные вопросы и исправить имеющиеся дефекты. Возможны следующие варианты:

- рассмотрение тем же составом арбитров, который ранее вынес соответствующее арбитражное решение;

- рассмотрение новым составом;

- комбинированный вариант - частичная замена прежнего состава новыми арбитрами.

Вероятнее всего, наиболее верным вариантом является первый, так как состав арбитража уже ранее был знаком с данным делом, разрешал спор и выносил решение, следовательно, соблюдается критерий экономии времени и средств. При этом не стоит забывать о том, что арбитр рассматривает не одно дело в год, более того он может заниматься 
частной практикой или работать в юридической фирме. В связи с этим необходимо поставить данный тезис под сомнение, так как возможно тому же составу, который ранее рассматривал дело, понадобится затратить аналогичное время, которое бы понадобилось новому составу арбитража. Также данный вариант нельзя признать универсальным, так как дефект может заключаться в нарушении порядка формирования состава арбитража, его беспристрастности и независимости, в таком случае рассмотреть ремитированные вопросы в прежнем составе не представляется возможным [14]. Важно учитывать, что при исправлении дефектов в том же составе возможно поставить арбитров в неловкое положение. С одной стороны есть вероятность того, что арбитр может быть небеспристрастным, так как не захочет признавать ошибки в собственном решении, с другой - появится риск отмены решения арбитража, что может повлиять на профессиональную репутацию арбитра.

Российская доктрина полагает, что, если ремитированные вопросы не могут быть рассмотрены в прежнем составе, а значит необходим новый состав арбитража, то процедура ремиссии нецелесообразна. Решение арбитража следует отменить, а сторонам повторно обратиться в арбитраж за разрешением спора. Нецелесообразной в данном случае ремиссия признается по обстоятельствам несоответствия критерию времени и расходов, то есть сторонам потребуется время на поиск новых арбитров, а арбитрам на ознакомление с делом [5]. Однако хочется отметить, что аналогичное время может быть потрачено, если дело будет рассматриваться тем же составом, так как арбитры могут не иметь возможности оперативно рассмотреть ремитированные вопросы в силу имеющейся загруженности. На практике известен только один случай рассмотрения ремитированных вопросов новым составом арбитража [17].

Предлагается также комбинированный вариант, когда дело было рассмотрено, например, в составе трех арбитров, из которых один никак не может принять участие в исправлении дефектов, тогда арбитр будет заменен. В данном вопросе требуется в первую очередь согласованность сторон, а во вторую соответствие критерию экономии времени и расходов.
В качестве примера предлагается рассмотреть п. 10 ст. 36 Арбитражного регламента CEPANI, из которого следует, что исправлять дефекты должен тот состав, который разрешал спор и выносил решение. В том случае, если невозможно рассмотреть ремитированные вопросы в том же составе, состав арбитража формируется в соответствии со ст. 17 Арбитражного регламента CEPANI. В п. 1 данной статьи в случае смерти арбитpa, принятии отвода, отзыва арбитра или просьбы сторон арбитр будет заменен. Также он может быть заменен, если Комитет по назначениям или председатель посчитают, что он не может исполнять свои обязанности в соответствии с регламентом и в заданные сроки. По новому арбитру стороны могут представить свои замечания. Решение по назначению принимает Комитет по назначениям либо председатель. Таким образом, заслуга Бельгийского центра арбитража и посредничества в том, что в их регламенте предусмотрена и регламентирована процедура формирования состава арбитража при проведении процедуры ремиссии.

Определяющей в вопросе о составе третейского суда должна быть воля сторон. Рассмотренные выше варианты могут иметь как положительные, так и отрицательные аспекты, поэтому рассмотрение вопросов и исправление дефектов новом, прежним или комбинированным составом должно во много определяться сторонами. При этом необходимо предусмотреть и роль государственного суда, за которым должно быть закреплено окончательное право по решению вопроса о составе арбитража на случай недобросовестности сторон.

Необходимо также рассмотреть вопрос о пределах действия мандата арбитров при ремиссии. Предлагается выделить 2 возможных варианта:

1) мандат арбитров действует только по тем вопросам, по которым необходимо исправить дефекты;

2) мандат арбитров действует на все решение арбитража.

В данном случае значительная роль отводится государственному суду, который возвращает решение арбитража. Суд в своем же решении указывает, где именно и по каким 
вопросам необходимо внести изменения, таким образом обозначая действие мандата арбитров [16]. При этом следует учитывать взаимосвязь отдельных вопросов. Например, государственный суд приходит к выводу о том, что арбитры ненадлежащим образом рассмотрели вопрос о заключении договора поставки, помимо этого в решении арбитража имеется пункт об убытках, причиненных данным договором. В связи с этим мандат арбитров должен быть расширен по вопросам исправления дефектов.

Рассмотрим подробнее приведенный пример о договоре поставки. Выше было установлено, что государственный суд определяет круг вопросов подлежащих ремиссии. Представим, что в решении в качестве ремитированного вопроса указан только договор поставки и ничего не сказано об убытках. Как в данном случае поступить составу арбитража? С одной стороны, рассмотрение вопросов, не указанных в решении государственного суда, будет означать выход за пределы мандата. С другой - нерассмотрение всех необходимых вопросов составом арбитража поставило бы под вопрос целесообразность самой ремиссии. Правильно ли дать возможность арбитрам в таком случае самостоятельно исправлять дефекты по тем вопросам, которые не были указаны в качестве ремитированных государственным судом? Вероятнее всего - нет, так как в таком случае есть риск столкнуться с произволом со стороны состава арбитража. Состав арбитров должен уведомить государственный суд о необходимости исправления дефектов также и по другим вопросам [13]. После одобрения со стороны государственного суда состав арбитров может приступить к исправлению.

Имеет ли право арбитраж отказаться от ремиссии? Обязанности принять ремитированные вопросы и исправить дефекты однозначно не существует. Формально арбитраж может отказаться от процедуры ремиссии. Следуя такому решению, арбитры не подвергают себя практически никакому риску, так как отсутствуют какие-либо санкции за такие действия, кроме вероятности отмены решения арбитража. Процедура ремиссии строится на взаимодействиях государственного суда и арбитража. Третейский суд не должен необос- нованно отказываться от ремиссии, его несогласие должно быть обосновано и представлено суду. В свою очередь, государственному суду не следует сразу же отменять решение арбитража при его несогласии.

\section{3. Форма акта арбитража по резуль- татам ремиссии}

Возникает вопрос о решении, которое примет арбитраж по окончанию исправления дефектов, так как арбитраж может принять по делу новое или дополнительное решение. Возможна ли ситуация, когда арбитраж в зависимости от обстоятельств будет принимать либо новое решение, либо дополнительное или форма акта будет определена заранее и применима во всех случаях? В России существует два различных примера разрешения данного вопроса. Первый, когда арбитраж выносит новое решение (Определение Арбитражного суда Ростовской области от 11 января 2019 г. по делу № А53-19347/2018; постановление АС Уральского округа от 20 февраля 2018 г. № Ф09-652/18 по делу № А07-1154/ 2017). Второй, когда государственный суд принимает постановление о внесении изменений или об изложении арбитражного решения в новой редакции. Процедура выглядит следующим образом: государственный суд, найдя противоречия, которые являются устранимыми, а также учитывая волю сторон, которая направлена на приостановление производства до установления указанных противоречий, может приостановить производство по делу до момента устранения недостатков третейским судом (Определение Арбитражного суда города Москвы от 07 ноября 2018 г. по делу № A40-203696/18-83-1103). Затем уже в последующих судебных разбирательствах суд излагает в судебном акте редакцию третейского суда до устранения недостатков и после, тем самым, исправление дефектов реализуется не в акте арбитража, а в судебном акте государственного суда (Определения Арбитражного суда города Москвы от 12 апреля 2019 г. по делу № А40-203696/18-83-1103). В таком случае проблематично говорить о форме акта арбитража по результатам третейского суда, точнее не приходится, так как новая редакция находит свое отражение в судебном акте. Данный подход нельзя признавать 
в качестве подхода определения формы акта третейского суда по результатам ремиссии, так как непосредственно акт арбитража отсутствует.

В связи с этим предлагается выделить 2 подхода:

1) принятие арбитражем нового решения;

2) принятие арбитражем дополнительного решения.

Рассмотренные выше арбитражные регламенты иностранных арбитражных учреждений не выдвигают строгих требований по форме акта. Арбитраж после рассмотрения ремитированных вопросов может вынести как дополнительное решение, так и принять новое. Стоит отметить, что вопрос о форме акта арбитража по результатам ремиссии не имеет существенного практического значения, так как в любом случае стороны спора будут следовать последним актам, которые были приняты третейским судом.

\section{Заключение}

Институт ремиссии отвечает всем требованиям третейского разбирательства, соответствует критерию экономии времени и средств, позволяет избежать отмены арбитражного решения, что имеет колоссальное значение для контрагентов. Для успешной реализации ремиссии необходимо иметь порядок проведения данной процедуры, предлагается следующая редакция статьи о ремисии, которая могла бы быть закреплена в арбитражных регламентах арбитражных учреждений:

«Статья **. Процедура ремиссии.

1. В том случае, если государственный суд возвращает решение арбитража, то к такому третейскому разбирательству применяются правила арбитража.

2. Если сторонами определены условия возвращения решения арбитража третейскому суду, то государственный суд должен оказывать содействие в соблюдении данных условий.

3. Государственный суд может установить аванс на покрытие любых дополнительных расходов и гонораров состава арбитража, а также дополнительных административных расходов третейского суда.

4. Секретариат постоянно действующего арбитражного учреждения (или же иной орган) должен оказывать содействие составу арбитража и исполнить все требования решения суда, если это необходимо.

5. Ремитированные вопросы должен рассматривать тот же состав арбитража, который выносил решение арбитража. Если прежний состав арбитража восстановить невозможно, тогда состав арбитража восстанавливается в соответствии со статьей (Замена арбитра). По общему согласию сторон рассматривать ремитированные вопросы может новый состав арбитража. Прежний состав арбитража не может рассматривать вопросы в том случае, если дефект непосредственно связан с составом арбитража, например нарушение порядка формирования состава арбитража.

6. Мандат арбитров определяется кругом ремитированных вопросов, которые обозначены в решении государственного суда. Если для исправления дефектов необходимо рассмотреть также и иные вопросы, которые не входят в мандат арбитров, состав арбитража должен уведомить государственный суд о необходимости исправления дефектов также и по другим вопросам. После одобрения состав арбитров может приступить к исправлению.

7. Если состав арбитража отказывается от ремиссии, то он должен предоставить обоснование такого отказа государственному суду. В случае если последний согласен с обоснованием, решение арбитража сохраняет силу. В случае несогласия состав арбитража должен провести повторное рассмотрение.

8. По результатам ремиссии состав арбитража принимает либо новое решение, либо дополнительное, а также направляет его в государственный суд и сторонам».

Таким образом, в работе была представлена ремиссия как зарождающийся инструмент в российском праве, были проанализированы вопросы применимого права, состав арбитража, мандат арбитров, отказ арбитров от ремиссии, форма акта по результатам рассмотрения ремитированных вопросов [18]. Каждый раздел далеко неоднозначен и имеет свои подразделы, которые важны для выработки общего правопонимания. Важным результатом на сегодняшний день следует признать существование общих правил ремиссии, которые выводятся из положений о ремиссии иностранных арбитражных регла- 
ментов. Процедура ремиссии - это возможность избежать отмены арбитражного решения, а значит, соответствовать критерию времени и расходов, успешному исполнению решения арбитража и дальнейшему развитию предпринимательской деятельности. Институт ремиссии является элементом безопасности бизнеса [19]. Принятие положений о ремиссии в российских арбитражных регламентах будет способствовать развитию института ремиссии. Все результаты, полученные в процессе изучения данной темы могли бы быть рекомендованы к включению в арбитражные регламенты.

\section{ПРИМЕЧАНИЕ}

${ }^{1}$ Работа выполнена при финансовой поддержке Гранта Президента РФ № НШ-2668-2020.6 «Национально-культурные и цифровые тренды социально-экономического и политико-правового развития Российской Федерации в XXI веке».

This work was financially supported by the Grant of the President of the Russian Federation No. HU-2668-2020.6“National-Cultural and Digital Trends in the Socio-Economic, Political and Legal Development of the Russian Federation in the $21^{\text {st }}$ Century".

\section{СПИСОК ЛИТЕРАТУРЫ}

1. Андреев, Д. А. Теоретические и практические проблемы ремиссии в арбитраже / Д. А. Андреев // Новые горизонты международного арбитража. -2020. - Вып. 6. - С. 224-249.

2. Арбитражный регламент Венского международного арбитражного центра. - 2018. - Доступ из справ.-правовой системы «КонсультантПлюс».

3. Арбитражный регламент Международной торговой палаты. - 2017. - Доступ из справ.-правовой системы «КонсультантПлюс».

4. Закон РФ о международном коммерческом арбитраже: от 7 июля 1993 г. № 5338-1 (ред. от 29.12.2015) // Ведомости СНД и ВС РФ. - 1993. № 32. - Ст. 1240.

5. Курочкин, С. А. Третейское разбирательство и международный коммерческий арбитраж / С. А. Курочкин. - М. : Статуг, 2017. -286 c.

6. Международный коммерческий арбитраж : учебник / С. А. Абесадзе [и др.] ; отв. ред. Т. А. Лунаева ; науч. ред. О. Ю. Скворцов, М. Ю. Савранский, Г. В. Севастьянов. -2-е изд., перераб. и доп. - СПб. : Третейский суд ; М. : Статуг, 2018. - Вып. 9. - 965 с.
7. Практика применения Арбитражного процессуального кодекса Российской Федерации / О. В. Абознова [и др.] ; отв. ред. И. В. Решетникова. 5-е изд., перераб. и доп. - М. : Юрайт, 2018. - 480 с.

8. Регламент Арбитражногоцентра при РСПП.2018. - Доступ из справ.-правовой системы «КонсультантПлюс».

9. Русакова, Е. П. Интегрирование современных цифровых технологий в судопроизводство Китайской Народной Республики и Сингапура / Е. П. Русакова // Государство и право. - 2020. - № 9. - С. 102-109.

10. Федеральный закон «Об арбитраже (третейском разбирательстве) в Российской Федерации» от 29.12.2015 № 382-Ф3 (ред. от 27.12.2018) // Российская газета. - 2015. - Дек. (№ 297).

11. Хвалей, В. В. Новое законодательство об арбитраже: жить стало лучше, жить стало веселее / В. В. Хвалей // Закон. - 2016. - № 5. - С. 87-95.

12. CEPANI Arbitration Rules in force as from 1 January 2020. - 2020. - Access from Reference Legal System "KonsultantPlyus".

13. Financial and Economic Security of Business as a Primary Element in the Economic System/ D. D. Burkaltseva [et al.] // Espacios. - 2017. Vol. 38, № 33. - P. 3 .

14. Fleetwood Wanderers Ltd. (t/a Fleetwood Town Football Club) v. AFCFylde Ltd., [2018] EWHC 3318 (Comm.). - Electronic data. - Mode of access: https://www.casemine.com/judgement/uk/5c075b872 c94e 06166865 cdd.

15. Gessel-Kalinowska vel Kalisz, B. Uncitral Model Law: Composition of the Arbitration Tribunal Re-Considering the Case upon Setting Aside of the Original Arbitration Award / B. Gessel-Kalinowska vel Kalisz // Journal of International Arbitration. - 2017. Vol. 34, iss. 1. - P. 30-31.

16. LW Infrastructure Pte. Ltd. v. Lim Chin San Contractors Pte. Ltd., [2014] 1 SLR 1221.

17. Miller Construction Ltd. v. James Moore Earthmoving ([2000] EWHC Technology 52). Electronic data. - Mode of access: https:// www.casemine.com/judgement/uk/5a8ff73460d03e7f57 ea9a0f.

18. Rusakova, E. P. Industrial and Manufacturing Engineering in Ddigital Legal Proceedings in the AsiaPacific Region: A New Level of Quality Based on Data, Blockchain and AI / E. P. Rusakova, A. O. Inshakova // International Journal for Quality Research. - 2021.Vol. 15, № 1. - P. 273-289.

19. Tarakanov, V. V. Information Society, Digital Economy and Law / V. V. Tarakanov, A. O. Inshakova, V. V. Dolinskaya // Studies in Computational Intelligence. -2019. - Vol. 826. - P. 3-15.

20. The Common Law Procedure Act, 1854,17 \& 18 Vict. C.125. - Access from Reference Legal System "KonsultantPlyus". 


\section{REFERENCES}

1. Andreev D.A. Teoreticheskie i prakticheskie problemy remissii v arbitrazhe [Remission in Arbitration: Theory and Practice]. Novye gorizonty mezhdunarodnogo arbitrazha [New Horizons of International Arbitration], 2020, iss. 6, pp. 224-249.

2. Arbitrazhnyy reglament Venskogo mezhdunarodnogo arbitrazhnogo tsentra [Arbitration Rules of the Vienna International Arbitration Center], 2018. Access from Reference Legal System "KonsultantPlyus".

3. Arbitrazhnyy reglament Mezhdunarodnoy torgovoy palaty [Arbitration Rules of the International Chamber of Commerce], 2017. Access from Reference Legal System "KonsultantPlyus".

4. Zakon RF o mezhdunarodnom kommercheskom arbitrazhe: ot 7 iyulya 1993 g. № 53381(red. ot 29.12.2015) [The Law of the Russian Federation on International Commercial Arbitration of July 7, 1993 No. 5338-1 (As Amended on December 29, 2015)]. Vedomosti SND and VSRF, 1993, no. 32, art. 1240.

5. Kurochkin S.A. Tretejskoe razbiratel'stvo $i$ mezhdunarodnyj kommercheskij arbitrazh [Arbitration and International Commercial Arbitration]. Statut Publ., 2017. 286 p.

6. Abesadze S.A. et al. Mezhdunarodnyj kommercheskij arbitrazh: uchebnik [International Commercial Arbitration. Study Guide]. Saint Petersburg, Tretejskij sud; Moscow, Statut Publ., 2018, iss. 9.965 p.

7. Aboznova O.V. et al. Praktika primenenija Arbitrazhnogo processual'nogo kodeksa Rossijskoj Federacii [The Practice of Applying the Arbitration Procedural Code of the Russian Federation]. Moscow, Yurayt Publ., 2018. 480 p.

8. Reglament Arbitrazhnogo tsentra pri RSPP [Rules of the Arbitration Center at the RSPP], 2018. Access from Reference Legal System "KonsultantPlyus".

9. Rusakova E.P. Integrirovanie sovremennyh cifrovyh tehnologij v sudoproizvodstvo Kitajskoj Narodnoj Respubliki i Singapura [Integrating Modern Digital Ttechnologies Into the Legal Proceedings of the People's Republic of China and Singapore]. Gosudarstvo i pravo [State and Law], 2020, no. 9, pp. 102-109.
10. Federal'nyj zakon «Ob arbitrazhe (tretejskom razbiratel'stve) v Rossijskoj Federacii» ot 29.12.2015 № 382-FZ (red. ot 27.12.2018) [Federal Law No. 382-FZ Dated December 29, 2015 "On Arbitration (Arbitration Proceedings) in the Russian Federation" (As Amended on December 27, 2018)]. Rossiyskaya gazeta, 2015, December, no. 297.

11. Khvalei V.V. Novoe zakonodatelstvo ob arbitrazhe: zhit stalo luchshe, zhit stalo veselee [New Legislation on Arbitration: Life is Better, Life is Merrier]. Zakon [Law], 2016, no. 5, pp. 87-95.

12. CEPANI Arbitration Rules in Force As from 1 January 2020, 2020. Access from Reference Legal System "KonsultantPlyus".

13. Burkaltseva D.D. et al. Financial and Economic Security of Business As a Primary Element in the Economic System. Espacios, 2017, vol. 38, no. 33, p. 3.

14. Fleetwood Wanderers Ltd. (t/a Fleetwood Town Football Club) v. AFC Fylde Ltd., 2018. EWHC 3318 (Comm.). URL: https://www.casemine.com/ judgement/uk/5c075b872c94e06166865cdd.

15. Gessel-Kalinowska vel Kalisz B. Uncitral Model Law: Composition of the Arbitration Tribunal Re-Considering the Case upon Setting Aside of the Original Arbitration Award . Journal of International Arbitration, 2017, vol. 34, iss. 1, pp. 30-31.

16. L W Infrastructure Pte. Ltd. v. Lim Chin San Contractors Pte. Ltd., 2014. 1 SLR 1221.

17. Miller Construction Ltd. v. James Moore Earthmoving (2000. EWHC Technology 52). URL: https://www.casemine.com/judgement/uk/ 5a8ff73460d03e7f57ea9a0f.

18. Rusakova E.P., Inshakova A.O. Industrial and Manufacturing Engineering in Digital Legal Proceedings in the Asia-Pacific Region: A New Level of Quality Based on Data, Blockchain and AI. International Journal for Quality Research, 2021, vol. 15, no. 1, pp. 273-289.

19. Tarakanov V.V., Inshakova A.O., Dolinskaya V.V. Information Society, Digital Eeconomy and Law. Studies in Computational Intelligence, 2019, vol. 826, pp. 3-15.

20. The Common Law Procedure Act, 1854,17 \& 18 Vict. C.125. Access from Reference Legal System "KonsultantPlyus". 


\section{Information About the Authors}

Ekaterina P. Rusakova, Candidate of Sciences (Jurisprudence), Associate Professor, Department of Civil Law and Procedure and Private International Law, Peoples' Friendship University of Russia, Miklukho-Maklaya St, 10k3, 117198 Moscow, Russian Federation, rusakovaep@rudn.ru, https://orcid.org/0000-0001-6488-0754

Viktor V. Zaitsev, Student, Law Institute, Peoples' Friendship University of Russia, Miklukho-Maklaya St., 10k3, 117198 Moscow, Russian Federation, vickt.zayczev2012@yandex.ru, https://orcid.org/0000-0001-6088-0941

\section{Информация об авторах}

Екатерина Петровна Русакова, кандидат юридических наук, доцент кафедры гражданского права и процесса и международного частного права, Российский университет дружбы народов, ул. Миклухо-Маклая, 10к3, 117198 г. Москва, Российская Федерация, rusakovaep@rudn.ru, https://orcid.org/0000-0001-6488-0754

Зайцев Виктор Васильевич, студент юридического института, Российский университет дружбы народов, ул. Миклухо-Маклая, 10к3, 117198 г. Москва, Российская Федерация, vickt.zayczev2012@yandex.ru, https://orcid.org/0000-0001-6088-0941 